UDC 347.998.4)

DOI:10.5937/RKSPP1901237K

GORAN KOEVSKI

DARKO SPASEVSKI

\title{
TRENDS IN RESPECT OF SPECIALIZATION OF COMMERCIAL DISPUTES JUDICIARY
}

In this paper, the authors are analyzing the trends of the development of the specialization of courts in the field of commercial disputes. Through the analysis, the authors set forth the arguments "pro" and "against" the specialization of the judiciary in this legal field. Also, the authors are analyzing the models of specialization of the judiciary. Special attention is paid to analyzing the experiences of the United States of America, United Kingdom, Germany, France, Italy, Switzerland and the Netherlands, as well as countries from the region, such as Serbia, Croatia and Montenegro. The Macedonian judicial experience in this area is analyzed in both periods of development, the period before the abolition of the commercial courts and the period after their abolition.

Key words: Court Specialization, Judiciary, Commercial Courts, Commercial Disputes

\section{SPECIALIZATION OF JUDICIARY AND COMMERICAL DISPUTES - DEVELOPMENT AND CONTEMPORARY EXPERIENCES}

The specialization of the judiciary, in a variety of shapes, is encompassing an increasingly larger segment within the judicial system. As stated in the March 2012 report by the Working Party of the Working Party of the Consultative Coun-

Prof. Dr. Goran Koevski, Full Professor, University “Ss. Cyril and Methodius”, Faculty of Law "Iustinianus Primus", Skopje, North Macedonia, e-mail: g.koevski@pf.ukim.edu.mk

Dr. Darko Spasevski, Associate Professor, University "Ss. Cyril and Methodius", Faculty of Law “Iustinianus Primus”, Skopje, North Macedonia, e-mail:d.spasevski@pf.ukim.edu.mk 
cil of European Judges (CCJE): “The main reason for specialization of the judiciary is the increased specialization of the law itself and the growth of complex legal relations." In addition, another reason for specialization of courts is the social context, i.e. the needs of the society for courts to show greater expertise and efficiency. ${ }^{2}$ Also, the specialization present in the practise of law by attorneys and public prosecutor services, influences the specialization of the judiciary. ${ }^{3}$

The globalisation of commercial relations is also reflected in the globalisation of the judiciary in the area of commercial disputes. This refers to the creation of a specialised commercial judiciary intended to address as many foreign-related disputes as likely to be referred to an arbitration institution. Thus, such specialization represents a competition to arbitration dispute resolution. This process began in the UK and since then, has spread in France, Germany, Belgium and the Netherlands. On March 17, 2017, the French Minister of Justice requested the High Legal Committee of the Financial Market of Paris to prepare a report on the probability of establishing a specialised judicial department responsible for international commercial disputes under the Court of Appeal of Paris. ${ }^{4}$ These specialised judicial councils in France would comprise of judges with experience in commercial law, financial law, economics, as well as English language proficiency needed to conduct the procedure. ${ }^{5} \mathrm{~A}$ particular advantage for France, compared to Britain as its competitor after the Brexit, is the fact that France, as a member of the European Union, will benefit from the effects of automatic recognition and enforcement of judicial decisions in other EU member states. ${ }^{6}$

In the Netherlands, the new Dutch Commercial Court started work in 2018, whereby English and Dutch will be the languages of the proceedings, with specialization of judges, thus making the procedures more efficient and faster. ${ }^{7}$ The first case of this Court was the case of Elavon Financial Services DAC v. IPS Holding B.V. and others in February 2019.

1 Heike Gramckow, Barry Walsh, Developing Specialized Court Services - International Experiences and Lessons Learned, The World Bank, 2013, available at: http://documents.worldbank.org/ curated/en/688441468335989050/pdf/819460WP0Devel00Box379851B00PUBLIC0.pdf, 22.3.2018.

2 Ibidem, p. 9.

3 Ibidem, p. 9.

4 Ioana Knoll Tudor, "Specialized chambers for international commercial disputes: Paris in the spotlight”, Kluwer arbitration blog, 2018, available at: http://arbitrationblog.kluwerarbitration. com/2018/02/14/specialised-chambers-international-commercial-disputes-paris-spotlight/, 25.7.2019.

5 Ibidem.

6 Ibidem.

7 Ibidem. 
In Belgium, the International Commercial Court is envisaged to start work in Brussels, with proceedings and judgments adopted in English. The rules of procedure before this court are basically similar to those derived from arbitration rules. ${ }^{8}$ Until now, the proceedings in Belgian courts have been conducted in the official languages of Belgium, which is considered restrictive in international context. ${ }^{9}$ The subject of this court's proceedings would be disputes in the field of international commercial transactions. The purpose of this court is to operate in line with the principle of a one stop shop, i.e. the judgments of the court would be final without the possibility to appeal. ${ }^{10}$ Judges of this court shall be judges coming from Belgian courts. The jurisdiction of the court will be set out by the parties in their agreements. ${ }^{11}$

This trend has also been observed in Germany. Starting as of 2014, a pilot project was introduced in the court of Cologne, whereby proceedings requested by parties and cases of disputes with foreign elements, are conducted bilingually in both German and English. ${ }^{12}$ During this period, it is also envisaged for a separate department to be set up at the Frankfurt Regional Court ${ }^{13}$ whereby the procedure, at the request of the parties, may be fully conducted in English. ${ }^{14}$

The United States of America have also recognised the need for judiciary specialization in commercial disputes. The so-called constitutional courts have been operating within the United States pursuant to Article 3 of the US Constitution and the so-called legislative courts pursuant to Article 1 of the US Constitution. ${ }^{15}$ In the United States, in accordance with their powers, federal states also develop specialised commercial judiciary. Delaware's Court of Chancery is the first

8 Ibidem.

9 Carlo Persyn, "An international business court in Brussels: a modern step forward", available at: https://www.nautadutilh.com/en/information-centre/news/2017/11/an-international-business-courtin-brussels-a-modern-step-forward/, 10.4.2018.

10 Charles Price, "Brussels International Business Court", available at: https://cew-law.be/ brussels-international-business-court/?lang=en, 10.4.2018.

11 Ibidem.

12 Martin Huff, "LG Koln Goes International", available at: https://www.lto.de/recht/ hintergruende /h/modellprojekt-in-nrw-lg-koeln-goes-international/, 04.04.2018.

13 Christoph Just, "A New Landmark in International Commercial Litigation? - the Frankfurt high court installed a specialized chamber for international commercial matters", available at: https:// www.schulte-lawyers.com/schulteblog/2882017-6y2e6, 05.04.2018.

14 I. K. Tudor, op.cit.

15 Marcus Zimmer, “Overview of Specialized Courts", available at: https://www.iacajournal. org/articles/abstract/10.18352/ijca.111/, 20.03.2018. 
court in a separate federal state within the United States to specialise in commercial judiciary, founded in 1792. Having existed for more than two centuries, this court has created abundant case law and in this regard, has taken precedence over the courts of other US states. ${ }^{16}$ In addition, the case law that this court has developed over the years influences the content of future legislative acts that need to be adopted. ${ }^{17}$ Commercial departments in permanent courts have been established and fully operating in New York, Chicago, North Carolina, New Jersey, Philadelphia, Pennsylvania, Reno, Las Vegas, Massachusetts, Maryland, Orlando and Florida. ${ }^{18}$ In December 1998, Judge Kaye announced the expansion of the commercial department in Nassau, Erie and Westchester counties. ${ }^{19}$

In 1895, a Commercial Court was established in the United Kingdom as a specialized judicial branch of the Queen's Bench Division. This Court handles commercial disputes, banking and finance, commercial representation, managerial agreements, freight forwarding agreements, insurance and reinsurance, import and export, etc.

Judicial specialization has also been accepted in France. Namely, there are several specialised courts in France: trade courts (tribunal de commerce), labour courts (conseil de prud'hommes), agricultural courts (tribunal paritaire des baux ruraux) and social protection courts (tribunal des affaires de sécurité sociale). Commercial courts are one of the oldest specialised judicial institutions established since the Middle Ages. There are currently 135 commercial courts in France. The jurisdiction of these courts is commercial disputes are as follows: disputes between merchants, disputes arising from commercial documents, as well as bankruptcy proceedings. These courts are also in charge of maintaining court registries.

The specialization of Italy's commercial judiciary has been carried out by enhancing the competences of specialised intellectual property disputes departments by assigning additional competences in the broader area of commercial law. Namely, Article 2 of Decree No. 1 of 24 December 2012 of the Italian Parliament as part of Act No. 27 of 24 March 2012 provides for a reform in existing di-

16 Jill E. Fisch, "The Peculiar Role of the Delaware Courts in the Competition for Corporate Charters", University of Cincinnati Law Review, (May 2000), available at: https://ssrn.com/ abstract $=219550$ or http://dx.doi.org/10.2139/ssrn.219550, 21.04.2018.

17 Bach Mitchell, Lee Applebaum,"A History of Creation and Jurisdiction of Business Courts in the Last Decade", (November, 2004), The Business Lawyer, p. 152, available at: https:// www.jstor.org/stable/40688264?seq=1\#page_scan_tab_contents, 27.9.2018.

18 Ibidem, p. 153.

19 Ibidem, p. 154. 
visions of industrial property courts, their deeper specialization and widening the competencies in a broader range of areas within statutory commercial law. ${ }^{20}$

In Switzerland, large commercial disputes are usually settled by regular courts, but the cantons of Zurich, Bern, St. Gallen and Aargau have established specialized commercial courts that work very successfully. ${ }^{21}$ According to the Law on Civil Procedure, cantons can establish commercial courts in their territory as first instance courts for commercial disputes. ${ }^{22}$ The decisions of the cantonal commercial courts can only be appealed to the Supreme Court of Switzerland. Commercial disputes over which these courts have jurisdiction are disputes in which 1) the disputed matter is the business of at least one of the parties, 2) the value of the dispute is at least 30,000 Swiss francs, and 3) the parties have been registered as merchants in the Swiss Trade Register or in a similar foreign register. ${ }^{23}$ These three conditions must be met cumulatively. ${ }^{24}$

\section{REASONS FOR SPECIALIZATION IN THE TRADE DISPUTES FIELD - PROs and CONs}

Court specialization is a useful and efficient mechanism seeking to solve a wide range of issues, such as the need to effectively enforce contractual obligations, improve the business environment or better protect the rights of commercial entities. ${ }^{25}$

Various studies conducted in the United States of America and Australia have shown that the specialization of courts can lead to reduced length of court proceedings for complex cases requiring the expertise of the decision-makers and the parties involved in the procedure, which are mostly related to the areas of Bankruptcy Law, Environmental Law, Business Law, etc. ${ }^{26}$

Generally speaking, the reasons for specialization of courts or special court departments include the following:

20 Francesca Squillante, "The Institution of the Italian "Commercial Courts" and its Impact on Antitrust Damages Actions”, available at: iar.agcm.it/article/download/9453/8658, 22.03.2018.

21 Urs Feller, Marcel Frey, Bernhard C Lauterburg,"Litigation and Enforcement in Switzerland: Overview", available at: https://uk.practicallaw.thomsonreuters.com/1-502-1695?transitionType= De fault\&co ntextData $=($ sc. Default $) \& f i r s t$ Page $=$ trueぬ $b h c p=1,28.03 .2018$.
22 Ibidem.
${ }^{23}$ Ibidem.
${ }^{24}$ Ibidem.
25 H. Gramckow, B. Walsh, p. 5.
${ }^{26}$ Ibidem, p. 5. 
a) Efficiency improvement. The specialization of judges as well as administrative staff in specialized courts affects the efficiency of the procedure as well as the overall case management process;

b) The establishment of specialized courts and the transfer of cases also affect the unloading of general jurisdiction courts;

c) The specialization of judges leads to better quality decisions, especially in complex cases requiring more specific knowledge. Their vast experience and expertise will lead to better decisions that will result in better outcomes;

d) The introduction of specialized courts with special jurisdiction will lead to the creation of uniform case law in the particular area of jurisdiction which is likely lead to a greater degree of predictability of court decisions and increased confidence in courts, as well as an assumption to reduce appealed cases. ${ }^{27}$

Some studies also note certain considerations. For example, the establishment of specialized courts is considered a privilege of the addressee group concerned, while other entities should rely on courts with regular (general) jurisdiction. ${ }^{28}$ Some research indicates that the specialization of courts represents merely a duplication of the work of existing experts (an example of such dispute resolution mechanisms envisaged in construction disputes - dispute boards - composed of experts specializing in the issue), without supplementing any added value. ${ }^{29} \mathrm{In}$ addition, apart from the establishment of specialized courts, measures need to be taken to improve the situation in the overall justice system. It can be noted that in the short term, the transfer of cases from courts with general jurisdiction to specialized courts can have a positive impact in terms of relieving the former courts. Yet, if the change benefits only a smaller group of service users and the positive results are not transferred on to the entire judicial system, then the court's specialization process will be called into question. ${ }^{30}$ It is also considered that it might be more prudent to exploit funds needed to set up and operate specialized courts to improve courts of general jurisdiction. ${ }^{31}$ One observation is the fact that judges working in specialized courts may focus on a particular specialty, and at the same time narrow their view to other fields of the law, which may result in limiting their ability to take into account other parts of the law while deciding. With the specialization itself, the assumption is that judges, since they will work consistently with only a narrow circle of entities, can develop personal relationships with

27 Ibidem, p. 10. Also see: M. Zimmer, p. 2.

28 H. Gramckow, B.Walsh, p. 5.

29 Ibidem, p. 11.

30 Ibidem, p. 12.

${ }^{31}$ Ibidem, p. 5. 
these entities thus limiting their objectivity. ${ }^{32}$ These studies underpin that there is a risk of creating a closed circle of judges, lawyers and experts who deal only with cases under the jurisdiction of a specialized court and there is a risk of establishing informal relationships between them that can lead to special privileged relationships. Such a relationship, for some, is a risk that may affect the principle of impartiality especially for small jurisdictions. ${ }^{33}$

\section{MEHTODS OF IMPLEMENTING JUDICIAL SPECIALIZATION}

The specialization of courts can be conducted in various forms. The chosen model should correspond with the problem to be solved with the specialization and it can vary from country to country, depending primarily on the number of cases as well as the complexity of the cases covered by the specialization. ${ }^{34}$

Comparative practice shows the following models of organizational structure of specialized courts: a) the establishment of separate courts; b) the establishment of a separate judicial department or department within the existing court; c) the specialization of individual judges who will acquire special knowledge in a particular narrow area or of specialized judicial councils within an existing court.

In 1980, the United States Congress set up a Federal Courts Study Committee to investigate a number of issues and evaluate the work of specialized courts. In 1990, a special report of this Committee set out, inter alia, the criteria to determine when a specialized court could and should be established: 1) the subject matter of the dispute belongs to a separate area which may be divided from other law fields; 2) the area of specialization covers a large number of cases that are a burden on the existing courts and the redirection of these disputes to the specialized court will result in relieving the existing regular courts; 3 ) the cases cover matters of a technical and expert nature, the handling of which requires the judge to have special expertise; 4 ) there is uniformity in the administration of the subject area. ${ }^{35}$

Special criteria have also been given by Edward Cazalet who took into account the specifics of the English legal system. ${ }^{36}$

32 Ibidem, p. 5.

33 Ibidem, p. 12.

${ }^{34}$ For the specialization of the judiciary in general see: Dragana Kiprijanovska, “За концептот на специјализирано судство”, available at: $h t t p: / / i h r . o r g . m k / p . p h p ? p i d=329,11.04 .2018$.

35 Ibidem, p. 18.

${ }^{36}$ H. Gramckow, B. Walsh, p. 15. 
In terms of the actual jurisdiction entrusted to specialized commercial courts, there are also different approaches and solutions. The general rule is that there should be a clear distinction between the jurisdiction of specialized courts and the courts of general jurisdiction in order not to overlap their jurisdiction, that is, to avoid a situation where those are competing with each other and there is a conflict between them. ${ }^{37}$

\section{SPECIALIZATION OF JUDICIARY AND COMMERICAL DISPUTES - REGIONAL EXPERIENCES}

In the Republic of Croatia, the judicial power is exercised by regular and specialized courts and the Supreme Court of Croatia. ${ }^{38}$ The following specialized courts have also been envisaged in Croatia: Commercial Courts, Administrative Courts, the High Commercial Court, the High Administrative Court and the High Misdemeanour Court. ${ }^{39}$ The competences of the Commercial Courts are set out in Article 21 of the Law on Courts of the Republic of Croatia. In addition, the provisions of Article 34b of the Code of Civil Procedure are also relevant. ${ }^{40}$

Pursuant to Article 11 Paragraph 2 of the Law on the organization of courts in the Republic of Serbia there are regular courts and courts with special jurisdictions. ${ }^{41}$ The competences of the Commercial Courts of Serbia as courts of first instance are regulated by Article 25 of the Law on Courts. ${ }^{42}$ The second instance court for dealing with commercial disputes is the Commercial Court of Appeal, whose jurisdiction is regulated with Article 26 of the Law on Courts.

37 M. Zimmer, p. 5.

38 Article 14, Paragraph 2 of the Law on Courts, [Official Gazette (Narodne novine), no. 28/13, 33/15. 82/15, 82/16 and 67/18], available at: https://www.zakon.hr/z/122/Zakon-o-sudovima, (in Croatian), 14.9.2019 https://www.zakon.hr/z/122/Zakon-o-sudovima.

39 Ibidem, Article 14, Paragraph 3,

40 Law on Litigation Procedure [Official Gazette (Narodne Novine), no. 53/91, 91/92, 112/99, 88/01, 117/03, 02/07, 84/08, 123/08, 57/11, 148/11, 25/13, 89/14 and 70/19], available at: https:// www.zakon.hr/z/134/ Zakon-o-parni\%C4\%8Dnom-postupku, (in Croatian), 19.9.2019https://www. zakon.hr/z/134/Zakon-o-parni\%C4\%8Dnom-postupku.

${ }^{41}$ Law on the Organization of Courts, Official Gazette (Službeni glasnik RS), no. 116/2008, 104/2009, 101/2010, 31/2011, 78/2011, 101/2011, 101/2013, 106/2015, 40/2015, 13/2016, 108/2016, 113/2017, 65/2018, 87/2018, and 88/2018, available at: https://www.paragraf.rs/propisi/zakon_o_ uredjenju_sudova.html, (in Serbian), 15.3.2019. https://www.paragraf.rs/propisi/zakon_o_uredjenju_ sudova.html

42 Ibidem. 
The establishment of specialized commercial courts was also foreseen in the 2015 Law on Courts in Montenegro ${ }^{43}$. The Rules on the Specialized Commercial Court are contained in Articles 17 and 18 of the referred Law.

From the above stated, it can be concluded that in all three countries (Serbia, Croatia and Montenegro) specialized commercial courts have been established to resolve first instance commercial disputes. What is different in these countries is the second instance proceedings. Namely, in Serbia and Croatia, there is also second instance judicial specialization, while in Montenegro there is only one-instance commercial court.

\section{SPECIALIZATION OF THE JUDICIARY AND COMMERCIAL DISPUTES IN THE REPUBLIC OF NORTH MACEDONIA}

a) Development phases of the commercial judiciary in the Republic of North Macedonia

The specialization of the judiciary in the Republic of North Macedonia in any of the foregoing models is present in different areas of law (an example is the administrative judiciary). This is an indication of the advantages and the importance of specialization for the entire judiciary system.

Judicial reforms are among the key state priorities of the Republic of North Macedonia. One of the priorities listed in the "Economic Priorities Program 2018-2020", prepared by the Ministry of Finance, and published in January 2018, is the P5 priority which encompasses "strengthening the independence and capacity of the commercial courts", aimed at increasing the capacity of commercial departments within permanent courts.

The need to develop a specialized judiciary, as well as the promotion and development of alternative ways of resolving disputes have also been noted in the 2019 European Union Progress Report on EU membership for North Macedonia. ${ }^{44}$ According to the data presented in the 2018 Progress Report on EU membership for North Macedonia, in our country there are 25 judges per 100,000 inhabitants, whereas in the European Union there are 21.5 judges per 100,000 inhabitants. ${ }^{45}$ The fact that, on average, there are more judges working in North

${ }^{43}$ Law on Courts, Official Gazette (Službeni List CG), no. 11/2015, available at: https:// sudovi.me/podaci/vrhs/dokumenta/2171.pdf, (in Montenegrin), 03.09.2019.

44 "North Macedonia 2019 Report", available at: https://ec.europa.eu/neighbourhood-enlargement/ sites/near/files/20190529-north-macedonia-report.pdfhttps://ec.europa.eu/neighbourhood-enlargement/ sites/near/files/20190529-north-macedonia-report.pdf, 02.06.2019, p. 10.

45 Ibidem. 
Macedonia and procedures are still slower and less efficient shows that the proper allocation of judges and resources has not been made.

As a basic lex generalis law, the Law on Courts provides the basis for specialization of the judiciary. In this sense, Article 12, Paragraph (1) of this Law outlines that "the work of courts shall normally be carried out in specialized court departments. ${ }^{46}$ In addition, specialization of judges shall also be provided within the specialized judicial department. ${ }^{47}$

The Law on Courts provides for specialized courts in the field of administrative law. ${ }^{48}$

Given the fact that significant issues related to commercial relations have been delegated to first instance courts with extended jurisdiction, it is expected that first instance courts with extended jurisdiction will be directed to specialization in the area of commercial relations. Namely, the courts of first instance with expanded jurisdiction resolve: disputes in property matters, legal and other civil-legal relations of natural and legal entities, whose value is above EUR 50,000 in MK Dequivalent, unless the law provides for jurisdiction of another court; in commercial disputes in which both parties are legal entities or state bodies, as well as disputes over copyright and other related rights and industrial property rights; in bankruptcy and liquidation proceedings; in disputes for determining and ensuring enforced execution and disputes of domestic legal and foreign entities arising from their mutual commercial or trade relations. ${ }^{49}$

The judicial system of the Republic of North Macedonia used to practise the functioning of separate commercial courts acting as a separate judicial institution as of 1954 until the adoption of the Law on Courts in 1995, when these judicial institutions were abolished. ${ }^{50}$ In this regard, the motives for the abolition of the commercial judiciary (the District Commercial Courts and the Commercial Court of the Socialist Republic of Macedonia) remain unclear, given the fact that these times were marked by the transition to a market economy, the creation

46 Article 12, Paragraph (2) of the Law on Courts, Official Gazette of the Republic of Macedonіа (Службен Весник на Република Македонија) по. 58/2006, 62/2006, 35/2008, 150/2010, 83/2018 and 198/2018 and Official Gazette of the Republic of North Macedonia (Службен Весник на Република Северна Македонија) nо. 96/2019, (in Macedonian) - hereinafter “LC").

47 Article 12, Paragraph (3) of the LC.

48 Article 22 of the LC.

49 Article 31, Paragraph (2) of the LC.

50 Article 111 of the Law on Courts, Official Gazette of the Republic of Macedonia (Службен Весник на Република Македонија) по. 36/95, 45/95 and 64/2003. 
of commercial entities by market order and the privatization of social capital. Had the specialized commercial courts with proper expertise to handle complex cases during the transition and privatization period continued to operate, the outcome of certain historical processes might have been different.

For the first time, such courts were established in accordance with the Law on Commercial Courts of the Federal People's Republic of Yugoslavia ${ }^{51}$ of 1954, as well as the Law on Commercial Courts of the Socialist Republic of Macedonia. ${ }^{52}$ Pursuant to Article 2 of the Law on Commercial Courts of the Federal People's Republic of Yugoslavia, the commercial judiciary was organised through District Commercial Courts, High Commercial Courts and the Supreme Commercial Court. This approach was further extended by the 1976 Law on Regular Courts of the Socialist Republic of Macedonia. ${ }^{53}$ According to Article 31 of this Law, separate judicial institutions were envisaged as District Commercial Courts (based in Skopje, Bitola and Shtip) and a Commercial Court of Socialist Republic of Macedonia (based in Skopje). ${ }^{54}$ The Commercial Court of Macedonia, pursuant to the Law on the Regular Courts of Socialist Republic of Macedonia, Article 47, was supposed to decide: a) within the jurisdiction established by law, upon appeals against judgments and other decisions of District Commercial Courts; $b$ ) in first instance when stipulated by law; (c) resolve disputes concerning jurisdiction between District Commercial Courts.

51 Official Gazette of FPRY no. 31/54.

52 Official gazette of SRM no. 42/65.

53 Official gazette of SRM no. 10/76.

54 The jurisdiction of the District Commercial Courts under Article 45 of the Law on Regular Courts of the Socialist Republic of Macedonia provides for them: a) to adjudicate in first instance commercial and maritime disputes, disputes for damage compensation in which socio-political communities are parties; affiliated labor organizations, self-governing interest communities and other self-governing organizations and communities, regardless of the value of the subject matter in dispute; b) to conduct the proceedings and to adjudicate in first instance for commercial offenses; c) to adjudicate commercial disputes relating to the protection and use of inventions, specimens, models and marks and the right to operate a company; d) to carry out the procedure for enforced settlement and bankruptcy and the procedure for regular liquidation of affiliated labor organizations and to adjudicate disputes arising in the course of the proceedings irrespective of the value of the dispute and the nature of the parties to the dispute; e) to maintain a court register of affiliated labor organizations and other organizations provided by law; f) to carry out the enforcement of commercial court decisions in commercial disputes and commercial offenses, except for real estate; g) to settle commercial disputes between domestic legal entities and foreign natural or legal entities, as well as mutual commercial disputes of foreign natural or legal entities; $h$ ) to decide in first instance on the legality of individual acts in administrative-accounting disputes; i) to perform other activities established by law. 
b) Current situation of commercial disputes in the Republic of Macedonia

\begin{tabular}{|c|c|c|c|c|}
\hline $\begin{array}{c}\text { Commercial } \\
\text { Disputes by } \\
\text { year }\end{array}$ & $\begin{array}{c}\text { Unresolved } \\
\text { cases from the } \\
\text { previous year }\end{array}$ & $\begin{array}{c}\text { Newly ac- } \\
\text { cepted }\end{array}$ & $\begin{array}{c}\text { Total under con- } \\
\text { sideration }\end{array}$ & Resolved \\
\hline 2018 & 516 & 382 & 893 & 414 \\
\hline 2017 & 585 & 455 & 1032 & 516 \\
\hline 2016 & 716 & 249 & 964 & 341 \\
\hline 2015 & 929 & 626 & 1725 & 863 \\
\hline
\end{tabular}

Table 1: Number of commercial disputes in the Basic Court Skopje II - Skopje (Source: Annual Report on the Work of the Basic Court Skopje II - Skopje for 2018, 2017, 2016 and 2015)

\begin{tabular}{|c|c|c|c|c|}
\hline Bankruptcy & $\begin{array}{c}\text { Unresolved cases from } \\
\text { the previous year }\end{array}$ & $\begin{array}{c}\text { Newly ac- } \\
\text { cepted }\end{array}$ & $\begin{array}{c}\text { Total under } \\
\text { considera- } \\
\text { tion }\end{array}$ & $\begin{array}{c}\text { Re- } \\
\text { solved }\end{array}$ \\
\hline 2018 & 348 & 329 & 677 & 385 \\
\hline 2017 & 340 & 1226 & 1566 & 1218 \\
\hline 2016 & 242 & 227 & 469 & 180 \\
\hline 2015 & 597 & 394 & 997 & 751 \\
\hline
\end{tabular}

Table 2: Number of bankruptcy proceedings in the Basic Court Skopje II - Skopje (Source: Annual Report on the Work of the Basic Court Skopje II - Skopje for 2018, 2017, 2016 and 2015)

From the analysis of the data contained in Tables 1 and 2 which represent the movement trends of the number of cases in the area of commercial disputes and bankruptcy in the Basic Court Skopje II in Skopje, it can be concluded that there are a significant number of cases. If these cases were assigned to specialized commercial courts, on the one hand, the Basic Court Skopje II in Skopje would be relieved, whereas on the other hand, the very fact that a specialized court would concentrate on handling these cases would improve the efficiency and certainly shorten the duration of the proceedings.

\section{CONCLUSION}

Possessing specialized knowledge and expertise of the subject matter in dispute resolution and adjudication is of great benefit to the parties in the dispute. As the parties are brought before a court with a capacity, knowledge and skills to decide complex cases, the basic precondition for effective legal protection and adjudication is provided within short time periods.

Specialization of the judiciary in various forms is present in many countries worldwide. In this regard, the modalities of introducing judicial specialization 
are most often present in the model of establishing separate autonomous judicial institutions competent for resolving commercial law disputes and the model of establishing specialized judicial departments that will deal with commercial law cases. The model to be introduced shall depend on a number of general factors specific to the particular country, including the social, sociological, cultural and economic context.

It is not by accident that special interdisciplinary scientific fields have been developing, such as economic analysis of law and neo-institutionalism, whose methodological approach could help make a particular political decision as to whether, and what specialized courts are needed in one country, including the Republic of North Macedonia.

The globalisation of commercial relations has also led to globalisation of justice. There is an increasing number of examples on the establishment of specialized court departments for foreign-trade disputes, which incorporate elements of arbitration in their proceedings and, in some ways, present competition to arbitration institutions. Examples of this can be found in the UK, Germany, France, and the Netherlands.

From the above stated it can be noted that there are certain parameters that help to assess the justification for judicial specialization. Within these parameters we can specify: a) the number of subject matters encompassed with the specialization, b) the complexity of the cases, c) the length of their final settlement, d) the size of the country and the number of inhabitants, e) the capacity to implement specialization - above all, a sufficient number of specialized staff; f) the range of legal areas entrusted to the specialized judiciary, etc.

Regional experiences embrace the model of specialized commercial judiciary through the formation of separate commercial courts. Such examples in the region are present in countries larger in territory and population than North Macedonia (Serbia and Croatia), but also in smaller ones than North Macedonia (Montenegro). In these three countries, the model of establishing a separate judicial institution specialized for commercial disputes in first instance has already been accepted, while in Serbia and Croatia the establishment of a second instance specialized court disputes institution has also been envisaged. The experience of the judiciary system in the Republic of North Macedonia shows that the specialization of the courts is present in one or another model. In certain areas of law, there are special judicial instances, in first and second instance (the example of the Administrative Court and the Higher Administrative Court of the Republic of North Macedonia), or specialization in other areas of the former is organised in separate specialized judicial departments. 
If we analyse the comparative experiences, as well as the generally accepted parameters that determine the need to establish a specialized court or not, in the context of our position on the formation of separate specialized commercial courts, we can conclude that:

- The establishment of a specialized commercial court will have a positive effect on the overall judiciary system in the Republic of North Macedonia and it will lead to improved efficiency in resolving commercial disputes,

It would be appropriate for such institutions to be established in first and second instance following the example of the administrative judiciary already established, which would be based in Skopje, competent for the entire territory of the Republic of North Macedonia (as a variant, the first instance commercial judiciary could be arranged with separate seats for all four appellate areas), and

-The specialized commercial judiciary would have jurisdiction over a number of cases in the area of statutory commercial law, including insolvency law, commercial agreements, securities, intellectual property rights and even labour disputes in the part of the so-called managerial agreements, given their particular legal nature.

Prof. dr GORAN KOEVSKI

redovni profesor Pravnog fakulteta

Univerziteta "Sv. Kiril i Metodije", Skoplje

Dr DARKO SPASEVSKI

docent Pravnog fakulteta

Univerziteta "Sv. Kiril i Metodije", Skoplje

\section{TRENDOVI U VEZI IZDVAJANJA PRIVREDNIH SUDOVA KAO SUDOVA POSEBNE NADLEŽNOSTI}

\section{Rezime}

U radu autori analiziraju trendove razvoja sudova posebne nadležnosti u oblasti privrednog prava. Autori kroz analizu iznose argumente "za" i "protiv" specijalizacije pravosuđa u ovoj oblasti. Takođe, u radu je ukazano na forme specijalizacije pravosuđa. Posebna pažnja posvećena je analizi stanja u Sjedinjenim Američkim Državama, Velikoj Britaniji, Nemačkoj, Francuskoj, Italiji, Švajcarskoj i Holandiji i zemljama iz regiona, kao što su Srbija, Hrvatska i Crna Gora. Iskustvo Makedonije analizirano je u oba perioda razvoja, u periodu pre ukidanja privrednih sudova $i$ u periodu nakon njihovog ukidanja.

Ključne reči: sudovi posebne nadležnosti, pravosuđe, privredni sudovi, privredni sporovi 


\section{Bibliography}

\section{Publications}

Feller Urs, Marcel Frey and Bernhard C Lauterburg, Litigation and Enforcement in Switzerland: Overview, available at: https://uk.practicallaw.thomsonreuters.com/1-5021695?transitionType $=$ De fault\&co ntextData $=($ sc. Default $)$ \& firstPage $=$ true\& $b h c p=1$, 28.03.2018.

Fisch Jill E., “The Peculiar Role of the Delaware Courts in the Competition for Corporate Charters", University of Cincinnati Law Review, (May 2000), available at: https://ssrn. com/abstract=219550 or http://dx.doi.org/10.2139/ssrn.219550, 21.04.2018.

Gramckow Heike, Walsh Barry, "Developing Specialized Court Services - International Experiences and Lessons Learned", The World Bank, 2013, available at: http://documents.worldbank.org/curated/en/688441468335989050/pdf/819460WP0Devel00Bo x379851B00PUBLIC0.pdf, 22.3.2018.

Huff Martin, "LG Koln Goes International", available at: https://www.lto.de/recht/ hintergruende /h/modellprojekt-in-nrw-lg-koeln-goes-international/, 04.04.2018.

Just Christoph, "A New Landmark in International Commercial Litigation? - the Frankfurt high court installed a specialized chamber for international commercial matters", available at: https://www.schulte-lawyers.com/schulteblog/2882017-6y2e6, 05.04.2018.

Kiprijanovska Dragana, “За концептот на специјализирано судство”, available at: http://ihr.org.mk/p.php?pid=329, 11.04.2018.

Mitchell Bach, Lee Applebaum, "A History of Creation and Jurisdiction of Business Courts in the Last Decade”, (November, 2004), The Business Lawyer, p. 152, available at: https://www.jstor.org/stable/40688264?seq=1\#page_scan_tab_contents, 27.9.2018.

North Macedonia 2019 Report, available at: https://ec.europa.eu/neighbourhood-enlargement/sites/near/files/20190529-north-macedonia-report.pdfhttps://ec.europa.eu/ neighbourhood-enlargement/sites/near/files/20190529-north-macedonia-report. pdf, 02.06.2019, p. 10.

Persyn Carlo, "An international business court in Brussels: a modern step forward", available at: https://www.nautadutilh.com/en/information-centre/news/2017/11/an-international-business-court-in-brussels-a-modern-step-forward/, 10.4.2018.

Price Charles, "Brussels International Business Court”, available at: https://cew-law.be/ brussels-international-business-court/?lang=en, 10.4.2018.

Squillante Francesca, "The Institution of the Italian "Commercial Courts" and its Impact on Antitrust Damages Actions", available at: iar.agcm.it/article/download/9453/8658, 22.03.2018. 
Tudor Ioana Knoll, "Specialized chambers for international commercial disputes: Paris in the spotlight", Kluwer arbitration blog, 2018, available at: http://arbitrationblog. kluwerarbitration.com/2018/02/14/specialised-chambers-international-commercialdisputes-paris-spotlight/, 25.7.2019.

\section{Legislative acts}

Law on Commercial Courts of the Federal People's Republic of Yugoslavia, [Official Gazette of FPRY (Службен лист на ФНРJ), nо. 31/54].

Law on Commercial Courts of the Socialist Republic of Macedonia, [Official gazette of SRM (Службен весник на СРM) no. 42/65].

Law on Courts [Official Gazette of the Republic of Macedonia (Службен Весник на Република Македонија) по. 58/2006, 62/2006, 35/2008, 150/2010, 83/2018 and 198/2018] and [Official Gazette of the Republic of North Macedonia (Службен Весник на Република Северна Македонија) по. 96/2019].

Law on Courts, [Official Gazette (Službeni List CG), no. 11/2015] available at: https://sudovi.me/podaci/vrhs/dokumenta/2171.pdf, (in Montenegrin), 03.09.2019.

Law on Courts, [Official Gazette of the Republic of Macedonia (Службен Весник на Република Македонија) по. 36/95, 45/95 and 64/2003].

Law on Litigation Procedure [Official Gazette (Narodne Novine), no. 53/91, 91/92, 112/99, 88/01, 117/03, 02/07, 84/08, 123/08, 57/11, 148/11, 25/13, 89/14 and 70/19], available at: https://www.zakon.hr/z/134/ Zakon-o-parni\%C4\%8Dnom-postupku, (in Croatian), 19.9.2019 https://www.zakon.hr/z/134/Zakon-o-parni\%C4\%8Dnom-postupku

Law on Regular Courts of the Socialist Republic of Macedonia, [Official gazette of SRM (Службен весник на СРМ) по. 10/76].

Law on the Organization of Courts [Official Gazette (Službeni glasnik RS), no. 116/2008, 104/2009, 101/2010, 31/2011, 78/2011, 101/2011, 101/2013, 106/2015, 40/2015, 13/2016, 108/2016, 113/2017, 65/2018, 87/2018, and 88/2018], available at: https:// www.paragraf.rs/propisi/zakon_o_uredjenju_sudova.html, (in Serbian), 15.3.2019.

Article history

Received: 29.09.2019.

Accepted: 07.10.2019. 